Maximilian Graf

\title{
Upside-down: Bilateral and Transnational Relations between Austria and Yugoslavia before and after 1948
}

The Austrian, Italian and Yugoslavian territorial conflicts (South Tyrol, Carinthia, Venezia Giulia and, most importantly, Trieste) were interconnected from postwar to Cold War and beyond. Overcoming mere national or bilateral approaches and analyzing those disputes within the international context makes the various mutual influences visible. ${ }^{1}$ By also addressing the transnational dimension of relations between the Communist parties, it becomes clear how multifaceted the connections were. ${ }^{2}$ This chapter argues that the Tito-Stalin split of 1948 constituted the decisive game changer at all levels. Thereafter, everything was upside-down. The example of bilateral and transnational relations between Austria and Yugoslavia demonstrates the sea change of the turbulent years before and after 1948. Beyond a mere analysis of the Austrian-Yugoslav postwar relationship from conflict to rapprochement, this study presents new findings on how this development was related to the question of Trieste.

\section{From Postwar to Cold War}

In 1945, relations between Vienna and Belgrade had hit rock bottom. Recovery of bilateral relations seemed almost impossible against the background of the Yugoslav war experiences (with many Austrians having fought in the German Wehrmacht in the Balkans), the subsequent deportation of German-speaking minorities from Yugoslav territory and the expropriation of their property, Yugoslavia's temporary military occupation of southern Austria, and its territorial demands on Carinthia and Styria. The

1 On the "Alps-Adriatic" region in the first postwar decade, see recently Mueller/Ruzicic-Kessler/Greilinger (eds.), The Alps-Adriatic Region.

2 On transnational relations in the "Alps-Adriatic" region see the special issue Comunismi di frontiera. I partiti comunisti nell'area Alpe-Adria 1945-1955. 
installation of an "Iron Curtain" and frequent killings at the border caused a frightening atmosphere. Early postwar contacts were rare. ${ }^{3}$

However, the interconnectedness of the territorial conflicts in the Alps-Adriatic region is especially evident in an Austrian-Yugoslav encounter in the spring of 1946. During the negotiations on the Italian Peace Treaty, Austria desperately fought a lost cause for the return of (at least part of) South Tyrol. It was within this context that $\mathrm{Yu}$ goslavia first attempted to instrumentalize Austria, by pointing out that both countries had territorial conflicts with Italy, and thus a "common enemy." Yugoslavia initiated a meeting between Austrian foreign minister Karl Gruber and the Yugoslav deputy foreign minister Aleš Bebler at the Mexican Embassy in Paris. Belgrade wanted Vienna to support its claims on Trieste. ${ }^{4}$ The overture was rejected by the Austrian government, because neither the state of burdened relations nor Austrian interests justified such a step. ${ }^{5}$ During his visit to Moscow in June 1946, Tito gave it another try and personally approached the Austrian diplomat Karl Braunias: After some warm words about his Austrian "comrades," like Franz Honner, Tito renewed the desire for an Austrian declaration supporting the Yugoslav claim on Trieste. ${ }^{6}$ However, Vienna did not consider Belgrade a trustworthy partner, not least because of the looming territorial demands on Carinthia. When Yugoslavia officially announced its territorial claims in the course of the opening negotiations on the Austrian State treaty at the turn of the year 1946, the postwar Cold War made any improvement of bilateral relations very unlikely. ${ }^{7}$

On the contrary, the Austrian communists praised the developments in Yugoslavia and highlighted the country's own contribution to its liberation from fascism. Already in April 1946, Yugoslavia was called the "freest, most democratic and progressed state of the non-Soviet world." As far as we now know, Austrian and Yugoslav communists had established close ties. Some leading Austrian communists had fought in the $\mathrm{Au}-$ strian battalions of the Yugoslav army at the end of the war. The party leaders met in September 1947 and discussed their politics. ${ }^{9}$ However, from 1945 to 1947 the Austrian Communist Party (Kommunistische Partei Österreichs, KPÖ) was part of the Austrian coalition government. ${ }^{10}$ Being in governmental responsibility, the KPÖ acted in Austria's

3 On Austrian-Yugoslav relations 1945-1955, see Suppan, Jugoslawien, pp. 431-447; Dragišić, Österreichisch-jugoslawische Beziehungen; Ibid., Odnosi Jugoslavije.

4 Amtsvermerk, Paris, 29 May 1946; and Norbert Bischoff an Generalsekretär Heinrich Wildner, Paris, 1 June 1946, Vertraulich!,ÖStA, AdR, BKA/AA, II-Pol 1946, Italien 9, Gr.Zl. 111.023-pol/46, GZ. 111.593-pol/46, Karton 14.

5 Amtsvermerk, Gegenstand: Triester Frage im Verhältnis zu Jugoslavien, Vienna, 2 June 1946; and Amtsvermerk, Gegenstand: Triester Frage; Verhältnis zu Jugoslavien, Vienna, 15 June 1946, ÖStA, AdR, BKA/AA, II-Pol 1946, Italien 9, Gr.Zl. 111.023-pol/46, GZ. 111.705-pol/46, Karton 14.

6 Politischer Vertreter Braunias an Bundesminister (BM) Gruber, Moscow, 11 June 1946, ÖStA, AdR, BKA/AA, II-Pol 1946, Gr.Zl. 111.801-pol/46, GZ. 111.814-pol/46.

7 On the territorial demands, see Stourzh, Um Einheit, pp. 63-67; Karner/Ruggenthaler, Stalin, Tito, pp. 81-105.

8 Die Kommunistische Partei Jugoslawiens, p. 221.

9 Mueller, Soviet Policy, pp. 90-115; Karner/Ruggenthaler, Stalin, Tito, pp. 98-99.

10 On the KPÖ 1945-55, see Mueller, Die sowjetische Besatzung; Mugrauer, Die Politik, pp. 37-52. 
national interest and rejected the Yugoslav territorial claims. At the same time, it heavily criticized the other Austrian parties for having failed in establishing friendly relations to Yugoslavia. Additionally, the Austrian communists demanded a genuine autonomy for the Slovene Carinthians and heavily criticized the alleged suppression of the minority by the regional and federal authorities. In communist interpretation, Austria's - of course questionable - minority policy and the problems of implementing minority rights in Carinthia, especially in public education, was a prolongation of the "German national and fascist policy" of deportation and annihilation. The KPÖ tried to justify its position and to provide the party members with "dialectic" arguments on how the party can on the one hand reject the territorial demands and on the other hand make the case for close relations to Yugoslavia. The clue lies in the subordination of the "national question" to the general "class struggle" and therefore the Austrian communist's struggle for a "People's Democracy." This position did not change until mid-1948. ${ }^{11}$ On the contrary, the KPÖ continued to praise the developments in Yugoslavia. In February 1948, the theoretical journal Weg und Ziel reported about the solution of the national question in Yugoslavia and stated, that Belgrade "had won the absolute confidence of its neighbors. Yugoslavia has become the spearhead of solid friendship of all freed people in the Balkans." ${ }^{12}$ In May 1948, chief editor Franz Marek praised the Yugoslav "popular front" and concluded: "the Yugoslav Peoples' Democracy is far ahead of other countries."13

\section{The Split and its Consequences}

Against this background, the Cominform Resolution constituted an unexpected blow to the Austrian communists. They were not informed in advance about the $\mathrm{Co}_{-}$ minform meeting on Yugoslavia. Paralyzed from shock, initially the KPÖ issued only the Resolution without commenting on it. The Osvobodilna Fronta in Carinthia rebuffed the Cominform critic and was heavily criticized for its course. The party branches in Carinthia and Styria were on the brink of falling apart. The split dazed not only ordinary party members, the same holds true for many functionaries. However, their dilemma was that even though they hardly believed the accusations against Tito, even more they were not able to think that "infallible" Stalin was wrong. One of those Austrian communists of two minds was Franz Marek, who as chief editor of Weg und Ziel had the ungrateful task to justify the whole situation in a special volume of the theoretical journal. ${ }^{14} \mathrm{He}$ fulfilled this task by sticking to the arguments of the critics by the Cominform accusing the Yugoslav leadership of having left the path of "internationalism" and

11 For more details, see Graf, The Austrian Communist's, pp. 50-52.

12 Der Sieg der wabren Demokratie, pp. 140-143.

13 Marek, Einheitslisten, Einheitsparteien und Volksdemokratie, p. 343.

14 Graf/Knoll (eds.), Franz Marek, p. 173. 
drifting towards "nationalism" - something the Austrian communists had experienced on the example of the territorial demands. The hardest part in writing this article was definitely the attempt to explain why the critic was made public and in how far this change can be understood in the light of the until then extremely positive communist news coverage on Yugoslavia. At least, Marek's article did not include terms like "fascists" or "agents of imperialism." 15 This constituted a remarkable difference to other authors who in the years to come discredited the Yugoslav leadership as "fascists," "imperialistic agents" and "traitors." 16 The campaign was reinforced after the show trials in Bulgaria and Hungary. The scripted confessions and judgments were presented as the ultimate proof of Yugoslav guilt. ${ }^{17}$ At home the party accused the "Tito clique" of the Osvobodilna Fronta to abuse of the national consciousness of the Slovenes in Carinthia and aiming at the decomposition of the Austrian workers. ${ }^{18}$ There is some evidence that the leading intellectual of the Austrian communists Ernst Fischer in his first reaction thought about siding with Tito. ${ }^{19}$ However, as a Stalinist he stuck with the party line and maybe in compensating his original position he set a peak to the condemnation of Tito. Fischer wrote a Stalinist propaganda play whose only aim was denouncing the Yugoslav leader as a "traitor." ${ }^{20}$

Soon, Austrian diplomats noted that the here to fore hostile Yugoslav media coverage on Austria had changed significantly. Now the polemics and attacks were directed against the Austrian Communists and especially Ernst Fischer as well as on Soviet policy in occupied Austria. ${ }^{21}$ This was an early reflection of the forthcoming rapprochement.

15 Marek, Was lehrtuns die Kritik an den Fübrern der KP Jugoslawiens?, pp. 569-596.

16 West, Die Spione von Belgrad, pp. 678-707.

17 On the KPÖ and the "show trials" in general, see Keller, Die KPÖ, pp. 199-218.

18 Mitteräcker, Die Tito-Clique in Kärnten, pp. 512-516.

19 "Many reports tend to confirm development of serious split in ranks of Austrian Communist Party as result of Cominform action against Tito. President Koplenig and General Secretary Fuernberg of Austrian Communist Party reportedly support Cominform while Communist nationalist Fischer defends Tito. Fischer accused of defection from soviet orbit many times in past and such schism may well be final contribution on Fischer's fall from power if break not healed soon. All efforts being made by Communists to keep these disputes from public. Osvobodilna Fronta, Carinthia branch of Austrian Communist Party which favors return [sic!] of South Carinthia to Yugoslavia, made formal break with Cominform supporters because of their current support of Tito. Fuernberg has been sent to Carinthia to attempt to strengthen pro-Cominform elements there.”Telegram (Weeka Austria) to Secretary of State, Vienna, 6 August 1948, NARA, RG 59, Central Decimal Files 1945-49, box 6852.

20 Fischer, Der große Verrat. Two decades later Fischer himself named writing this play "worse, than a mistake." Cf. Fischer, Das Ende, p. 271.

21 Politischer Vertreter Conrad-Eybesfeld an BKA/AA, Belgrade, 27 November 1948, Z1. 324-Pol/48, ÖStA, AdR, BKA/AA, II-Pol 1948, Jugoslawien 3, Gr.Zl.110.464-pol/48, GZ.118.988-Pol/48; Braunias an BM Gruber, Belgrade, 11 December 1949, Zl. 180-Pol/49, ÖStA, AdR, BKA/AA, II-Pol 1949, Jugoslawien 2, Gr.Zl. 80.333-pol/49, GZ. 89.567-Pol/49; Braunias an BM Gruber, Belgrade, 1 April 1950, Zl. 123-P/50, Geheim, ÖStA, BKA/AA, II-Pol 1950, Politische Berichte Belgrad, Karton 127; Gesandter Braunias an BKA/AA (Abt. 5), Belgrad, 5 April 1951, Zl. 184-P/51, ÖStA, AdR, BKA/AA, II-Pol 1951, Jugoslawien 6, GZ. 134.345pol/51. For details on the end of the "media war" and its continuation between the Communist parties, see Dragišić, Österreichisch-jugoslawische Beziehungen, pp. 149-157. 
Tito even giggled with Austrian diplomats over the insignificance of the Cominformists in the neighbor state. ${ }^{22}$ While the Austrian Communists had taken a clear-cut stance of condemnation on Tito, Austrian diplomacy cautiously followed the events in Yugoslavia and their potential consequences. In one of his first reports in mid-July 1947, the first Austrian post-1945 political representative in Belgrade Walter Conrad-Eybesfeld had written: "Russia's fist weighs heavy on Yugoslavia." ${ }^{23}$ Despite this, everybody was surprised when the split happened in 1948. A period of insecurity followed: From Soviet military intervention to reconciliation everything seemed possible. ${ }^{24}$ The repercussions of the split were manifest at all levels. When Karl Braunias, who had met Tito in Moscow in 1946, assumed office as the new Austrian political representative in Belgrade in late 1949, he noticed how these developments had also affected Tito personally: "When I first saw him in May 1946 in Moscow, he had a bright and rosy-cheeked face, like a young piglet. At my visit in November 1949, I looked into an aged and furrowed face." ${ }^{25}$ It took almost two years until Yugoslavia's position between East and West was considered permanent - at least for the time being. ${ }^{26}$ In the course of Belgrade's turn to the West, Austria and Yugoslavia started attempts to solve their existing problems at the bilateral level. The territorial demands were gradually reduced and (more importantly), from the beginning of 1949 they lacked Soviet support. ${ }^{27}$ In the early 1950s, semi-official Yugoslav statements foreshadowed their abandonment. ${ }^{28}$

In summer 1949, the promising negotiations on the Austrian state treaty had failed, probably due to Soviet military considerations. ${ }^{29}$ This view was shared by the Yugoslav leadership. With a smile on his face, Edvard Kardelj told an Austrian diplomat that maybe now the Yugoslavs are responsible for the delayed conclusion of the state treaty since Russia wants to keep its troops in Romania and Hungary because of Yugoslavia. In fact, their presence was - at least formally - only possible because of the occupation of Austria. ${ }^{30}$

22 Besuch bei Marschall Tito. Braunias an BM Gruber, Belgrad, 7 December 1950, Z1. 509-P/50, Geheim, ÖStA, BKA/AA, II-Pol 1950, Politische Berichte Belgrad, Karton 127.

23 Conrad-Eybesfeld an BM Gruber, Belgrade, 17 July 1947, Z1. 8-Pol/47, Vertraulich!,ÖStA, AdR, BKA/AA, II-Pol 1947, Jugoslawien 2, GZ. 108.259-pol/47.

24 See for example the numerous diplomatic reports of the years 1949/50:ÖStA, AdR, BKA/AA, II-Pol 1949 and 1950, Politische Berichte Belgrad.

25 Braunias recalled this impression in a report of May 1951, when reporting about discussions on Tito's health in Belgrade's diplomatic corps. Braunias an BM Gruber, Belgrade, 30 May 1951, Z1. 259-P/51, ÖStA, AdR, BKA/ AA, II-Pol 1951, Jugoslawien 49, Gr.Zl. 135.119, GZ.135.970-pol/51.

26 Amtsvermerk. Zwei Jahre Komintern konflikt, Vienna, 4 August 1950, ÖStA, AdR, BKA/AA, II-Pol 1950, Jugoslawien 2, Gr.Zl. 120.551-pol/50, GZ. 126.974-Pol/50.

27 Karner/Ruggenthaler, Eineweitere Unterstützung, p. 100.

28 Aufgabe der jugosl. Gebiets for der ungenge genüber Österreich - Erklärung PIJADES, Vienna, November 1951, ÖStA, AdR, BKA/AA, II-Pol 1951, Jugoslawien 2, Gr.Zl. 131.540-pol/51, GZ. 140.949-pol/51.

29 Mueller, Gab es eine, pp. 89-120.

30 Gespräch mit Kardelj, Braunias an BM Gruber, Belgrade, 10 February 1950, Z1. 41-P/50, Geheim!, ÖStA, BKA/AA, II-Pol 1950, Politische Berichte Belgrad, Karton 127. Also, see Bekes/Borhi/Ruggenthaler/Trasca (eds.), Soviet Occupation. 
In the years after the split, the situation at the Austrian-Yugoslav border normalized, economic cooperation between the neighboring states grew, and political relations improved. The Carinthian question turned into a question of the Slovene minority in Carinthia. ${ }^{31}$ When Braunias visited the Slovene national assembly in summer 1951, President Josip Vidmar told him: "For us Slovenes, it is not important if the Carinthian Slovenes live with us or in Austria. The borders will blur over time. For us, it is just important that the Slovene element in Carinthia has the freedom and possibility of its cultural development." 32 During the spectacular visit of Austrian foreign minister Karl Gruber to Yugoslavia in June 1952, even the minority problem was no longer an issue burdening the two countries' bilateral relations. For Tito, this visit was a way out of the isolation following $1948^{33}$ and, in fact, Austria had become a diplomatic "ice breaker" for a communist regime - long before "peaceful coexistence," the state treaty, and neutrality that shaped Austria's role towards the Socialist states throughout the Cold War. ${ }^{34}$

The Austrian-Yugoslav rapprochement was mischievously observed by Italy, ${ }^{35}$ especially because the conflict over Trieste worsened at the same time. From the beginning of 1952, Yugoslavia was increasingly interested in the Austrian position on Trieste, and once again Belgrade aimed at instrumentalizing Austria. Yugoslav diplomacy argued "that the question of Trieste could be easily solved if it were only a question between Austria and Yugoslavia. Austria had always shown understanding for Yugoslavia." Some even suggested: "Perhaps the best solution would be an Austrian governor in Trieste?"36 Austrian diplomats and politicians constantly had to assure the suspicious Italians that no Austrian diplomatic initiative regarding Trieste was planned. ${ }^{37}$ Even though Tito did not succeed in influencing Vienna's attitude to the question of Trieste, his personal engagement in the improvement of bilateral relations was strong. In his conversations with Austrian diplomats he openly spoke about his dislike for Stalin and his former Austrian "comrades." Additionally, the Yugoslav leader shared his considerations about Soviet policy. In an encounter with an Austrian diplomat in 1952, Tito called Stalin an "old donkey" and regarded the leadership of the Austrian communists as his "footmen," who someday would pay their price, like everybody else who worked for Stalin. Tito's assessment on the Austrian state treaty was bleak. ${ }^{38}$ This changed after Stalin's death in

31 For details on this process, see Dragišić, Österreichisch-jugoslawische Beziehungen, pp. 219-237.

32 Braunias an BM Gruber, Veldes, 29 August 1951, Z1. 390-P/51, Vertraulich!,ÖStA, AdR, BKA/AA, II-Pol 1951, Jugoslawien 2, Gr.Z1. 131.540-pol/51, GZ. 138.433-pol/51.

33 Dragišić, Österreichisch-jugoslawische Beziehungen, pp. 158-171.

34 On the term and later years, see Suppan/Mueller (eds.), "Peaceful Coexistence".

35 Graf, Österreich und Triest, p. 412.

36 Braunias an BM Gruber, Belgrade, 27 March 1952, Z1. 191-P/52, Geheim, ÖStA, AdR, BKA/AA, II-Pol 1952, Triest 2, Gr.Z1. 149.156-Pol/52, GZ. 150.104-Pol/52, Karton 208.

37 Graf, Österreich und Triest, pp. 414-415, 420-422.

38 Braunias an BM Gruber, Belgrade, 8 October 1952, Geheim, ÖStA, AdR, BKA/AA, II-Pol 1952, Jugoslawien 2, Gr.Zl. 146.175-pol/52, GZ. 157.193-Pol/52. 
1953, when he expected changes in the Soviet Union. In summer 1954, Tito predicted that Austria would be free within two years' time. ${ }^{39}$ In fact, the Austrian state treaty was concluded less than a year later. Naturally, it took time to solve all the problems between Austrian and Yugoslavia and some of them continued to cyclically burden relations, but the very years after 1948 had laid the basis for an exceptional (in ideological terms) East-West relationship of the Cold War era in which neutral Austria and non-aligned Yugoslavia positioned themselves between the blocs. ${ }^{40}$

On the contrary, relations between the Austrian and the Yugoslav Communists, which had been excellent after 1945, collapsed against the backdrop of the Tito-Stalin split. Before 1948, the KPÖ had blamed the Austrian government for not establishing close relations with Tito-Yugoslavia. When Austrian-Yugoslav relations started to normalize, the party publicly criticized this reconciliation and spoke of "US-puppets" in Vienna and Belgrade. Tito's warm words about Austria's independence were regarded as "hypocrisy." ${ }^{41}$ It was strictly forbidden to all party members to visit Yugoslavia or even to maintain contacts with "comrades" or relatives living in the Southern neighbor state. Any violation of these restrictions was likely to lead to an expulsion from the party. ${ }^{42}$ Tito held a very low opinion of his Austrian "comrades" and the re-establishment of party relations materialized only slowly after Nikita Khrushchev changed the Kremlin's stance in the mid-1950s. ${ }^{43}$ This was also a result of the "Stalinist" positioning of the KPÖ leadership and additionally influenced by the repercussions of the crackdown on the Hungarian uprising in 1956. Furthermore, Belgrade clearly prioritized the development of bilateral relations to Austria over interparty relations. ${ }^{44} \mathrm{With}$ the rapprochement looming on the horizon in 1957, the Austrian party's rank and file were puzzled, not least because Soviet-Yugoslav relations had worsened again in the aftermath of the Soviet intervention in Hungary. In various meetings of local party organizations, it became obvious that many ordinary party members had kept their propaganda inflicted "distrust against Tito." One even claimed: "Tito is and remains a bounder." 45 Against the revelations of Khrushchev's secret speech in 1956, ${ }^{46}$ some questioned whether the critique on the "Yugoslavian Communists in 1948 was wrong." ${ }^{47}$ The summary of

39 Botschafter Wodak an BM Figl, Bled, 12 August 1954, Zl. 55-Pol/54, ÖStA, AdR, BKA/AA, II-Pol 1954, Politische Berichte Belgrad, Karton 305.

40 On this development, see Portmann, Austria and Yugoslavia, pp. 435-464; Portmann and Ruzicic-Kessler, Yugoslavia and Its Western Neighbours, pp. 296-310.

41 Volksstimme, 18 June 1952; Spira, Die Titofaschisten - Bundesgenossen der Figl-Schärf-Regierung, pp. 588-596.

42 Meisel, Die Mauer, p. 110.

43 On the development of Soviet-Yugoslav relations 1953-1957, see Rajak, Yugoslavia.

44 Zabeleška povodom predloga da dolazi u Jugoslaviju nezvanična delegacija KP Austrije, 12 December 1956, AJ, ACKSKJ IX, 6/I-143; Informacija, Belgrade, 23 September 1957, AJ, ACKSKJ IX, 6/I-143.

45 Funktionär-Konferenz über das Juni-Plenum der KPdSU im XV. Bezirk, Report by Josef Lauscher, 12 July 1957, AÖGZ, Nachlass 40 (Josef Lauscher), DO 168, fol. 1037.

46 Mugrauer, Zwischen Erschütterung, pp. 257-297.

47 Funktionär-Konferenz über das Juni-Plenum der KPdSU im IX. Bezirk, Report by Josef Lauscher, 15 July 1957 , AÖGZ, Nachlass 40 (Josef Lauscher), DO 168, fol. 1048. 
another discussion read: "The relation to Yugoslavia and the role of Tito deeply troubled the comrades. Opinions differ." ${ }^{48}$ Later in the 1960s, the KPÖ refused to join the seminal re-enforcement of critique on Yugoslavia.

\section{Sources and literature}

\section{Archival sources}

Arhiv Jugoslavije (AJ), Belgrade, Arhiv Centralnog Komiteta Saveza Komunista Jugoslavije (ACKSKJ).

Archiv der Österreichischen Gesellschaft für Zeitgeschichte (AÖGZ), Vienna, Nachlass Josef Lauscher.

National Archives (NARA), Washington D.C., Record Group (RG) 59, Central Decimal Files 1945-49.

Österreichisches Staatsarchiv (ÖStA), Vienna, Archiv der Republik (AdR), Bundeskanzleramt/ Auswärtige Angelegenheiten (BKA/AA), Sektion II-Pol (II-Pol).

\section{Newspapers}

\section{Volksstimme}

Weg und Ziel

\section{Literature}

Bekes, Csaba, Laszlo Borhi, Peter Ruggenthaler and Ottmar Trasca (eds.), Soviet Occupation of Romania, Hungary, and Austria 1944/45-1948/49. Budapest: Central European University Press, 2015.

Dragišić, Petar, Österreichisch-jugoslawische Beziehungen 1945-1955, Dissertation, University of Vienna, 2007.

Dragišić, Petar, Odnosi Jugoslavije i Austrije 1945-1955. Belgrade: Institut za noviju istoriju Srbije, 2013.

Fischer, Ernst, Der große Verrat. Ein politisches Drama in fünf Akten. Vienna: Globus, 1950.

Fischer, Ernst, Das Ende einer Illusion. Erinnerungen 1945-1955. Vienna: Verlag Fritz Molden, 1973.

Graf, Maximilian, Österreich und Triest 1945-1955. Eine vergessene bistoire croisée des frühen Kalten Krieges. Römische Historische Mitteilungen 58 (2016), pp. 389-430.

Graf, Maximilian, The Austrian Communist's dealing with the Ideological and Territorial Conflicts in the Alps-Adriatic Region (1945-1955). Qualestoria. Rivista di storia Contemporanea XLV (2017) 1, pp. 43-61.

Graf, Maximilian, Austria and Trieste 1945-1955. Interconnected Histories of the Early Cold War. Wolfgang Mueller/Karlo Ruzicic-Kessler/Philipp Greilinger (eds.), The Alps-Adriatic

48 Funktionär-Konferenz über das Juni-Plenum der KPdSU bei der PO-Polizei, Report by Josef Lauscher, 16 July 1957, AÖGZ, Nachlass 40 (Josef Lauscher), DO 168, fol. 1062. 
Region 1945-1955. International and Transnational Perspectives on a Conflicted European Region. Vienna: new academic press, 2018, pp. 133-154.

Graf, Maximilian and Sarah Knoll (eds.), Franz Marek. Beruf und Berufung Kommunist. Lebenserinnerungen und Schlüsseltexte. Vienna: Mandelbaum, 2017.

Karner, Stefan and Peter Ruggenthaler, „Eine weitere Unterstützung der jugoslawischen Gebietsforderungen bring uns in eine unvorteilhafte Lage.“ Der Artikel 7 des Österreichischen Staatsvertrags als diplomatischer Kompromiss. Stefan Karner/Janez Stergar (eds.), Kärnten und Slowenien - „Dickicht und Pfade“. Klagenfurt: Hermagoras, 2005, pp. 99-118.

Karner, Stefan and Peter Ruggenthaler, Stalin, Tito und die Österreichfrage. Zur Österreichpolitik des Kreml im Kontext der sowjetischen Jugoslawienpolitik 1945 bis 1949. Jahrbuch für historische Kommunismusforschung. Berlin: Aufbau Verlag, 2008, pp. 81-105.

Keller, Fritz, Die KPÖ und die Schauprozesse in Osteuropa 1948 bis 1953. Wolfgang Maderthaner, Hans Schafranek and Berthold Unfried (eds.), „Ich habe den Tod verdient“. Schauprozesse und politische Verfolgung in Mittel- und Osteuropa 1945-1956. Vienna: Verlag für Gesellschaftskritik, 1991, pp. 199-218.

Meisel, Josef, Die Mauer im Kopf. Erinnerungen eines ausgeschlossenen Kommunisten 1945-1970. Vienna: Verlag für Gesellschaftskritik, 1986.

Mueller, Wolfgang, Die sowjetische Besatzung in Österreich 1945-1955 und ibre politische Mission. Vienna: Böhlau, 2005.

Mueller, Wolfgang, Gab es eine „verpasste Chance“? Die sowjetische Haltung zum Staatsvertrag 1946-1952. Arnold Suppan, Gerald Stourzh and Wolfgang Mueller (eds.), Der österreichische Staatsvertrag 1955. Internationale Strategie, rechtliche Relevanz, nationale Identität. The Austrian State Treaty. International Strategy, Legal Relevance, National Identity. Vienna: ÖAW, 2005, pp. 89-120.

Mueller, Wolfgang, Soviet Policy, Political Parties, and the Preparation for Communist Takeovers in Hungary, Germany, Austria, 1944-1946. East European Politics and Societies 24 (2010), pp. 90-115.

Mugrauer, Manfred, Zwischen Erschütterung, neuer Offenheit und “Normalisierung”: Die KPÖ, der 20. Parteitag der KPdSU und die Ungarn-Krise 1956. Wolfgang Mueller and Michael Portmann (eds.), Osteuropa vom Weltkrieg zur Wende. Vienna: ÖAW, 2007, pp. 257-297.

Mugrauer, Manfred, Die Politik der KPÖ 1945 bis 1955/56, in: ibid. (ed.), 90 Jahre KPÖ. Studien zur Geschichte der Kommunistischen Partei Österreichs. Vienna: Alfred Klahr Gesellschaft, 2009, pp. 37-52.

Portmann, Michael, Austria and Yugoslavia: Paths of a Difficult Neighbourhood, 1955-1991. Arnold Suppan and Wolfgang Mueller (eds.), Peaceful Coexistence or Iron Curtain? Austria, Neutrality, and Eastern Europe in the Cold War and Détente, 1955-1989. Vienna: Lit, 2009, pp. 435-464.

Portmann, Michael and Karlo Ruzicic-Kessler, Yugoslavia and Its Western Neighbours 19451980. Zeitgeschichte 41 (2014), 5, pp. 296-310.

Rajak, Svetozar, Yugoslavia and the Soviet Union in the Early Cold War: Reconciliation, Comradeship, Confrontation, 1953-1957. London: Routledge, 2010.

Stourzh, Gerald, Um Einheit und Freiheit. Staatsvertrag, Neutralität und das Ende der Ost-WestBesetzung Österreichs 1945-1955, 5. ed. Vienna: Böhlau, 2005. 
Suppan, Arnold, Jugoslawien und der österreichische Staatsvertrag. Arnold Suppan, Gerald Stourzh and Wolfgang Mueller (eds.), Der österreichische Staatsvertrag 1955. Internationale Strategie, rechtliche Relevanz, nationale Identität. The Austrian State Treaty. International Strategy, Legal Relevance, National Identity, Vienna: ÖAW, 2005, pp. 431-447.

Suppan, Arnold and Wolfgang Mueller (eds.), "Peaceful Coexistence" or "Iron Curtain?" Austria, Neutrality, and Eastern Europe in the Cold War and Détente, 1955-1989. Vienna: Lit, 2009.

\section{Summary \\ Maximilian Graf \\ Upside-down: Bilateral and Transnational Relations between Austria and Yugoslavia before and after 1948}

Postwar relations between Austria and Yugoslavia had been extremely tense and the incipient Cold War made the situation even worse. Among the reasons were the repercussions of World War II, the territorial conflict, the treatment of minorities, and the deepening East-West divide. This deadlock was rapidly overcome after the Tito-Stalin split of 1948 and the subsequent reorientation of Belgrade's policy towards the West. Fostered by Western support, bilateral relations started to reconcile and already in the early 1950s turned into an early example of détente between an - even though occupied - evolving Western style democracy and a - despite the split - Socialist regime. The situation at the border normalized, economic cooperation grew, and political relations improved. When Austrian foreign minister Karl Gruber visited Yugoslavia in 1952, the former conflictive issues played hardly any role and both sides started to work towards a good neighborly relationship. Tito was a driving force in this development and even exchanged his estimates of Soviet policy with Austrian diplomats at length. On the contrary, relations between the Austrian and the Yugoslav Communists, which had been excellent after 1945, collapsed against the backdrop of the Tito-Stalin split. The Austrian party followed Moscow's line, condemned Tito as a "traitor" (even though this caused severe internal conflicts) and furthermore deplored any rapprochement between Belgrade and Vienna. Hence, Tito held a very low opinion of his Austrian "comrades" and the re-establishment of party relations materialized only slowly after Khrushchev changed the Kremlin's stance in the mid-1950s. 